Special Issue of the 6th International Congress \& Exhibition (APMAS2016), Maslak, Istanbul, Turkey, June 1-3, 2016

\title{
Optimisation of Machining Parameters in Turning AISI 304L Stainless Steel by the Grey-Based Taguchi Method
}

\begin{abstract}
M. AY*
Marmara University, Faculty of Technology, Department of Mechanical Engineering, 34722, Istanbul, Turkey

In this study, an experimental optimization of cutting forces and surface roughness in turning of AISI 304L stainless steel using wiper and conventional insert cutting tools with dry cutting conditions are presented. The influences of feed rate, depth of cut, and corner radius on surface roughness, cutting force and surface hardness are examined. In order to optimize the turning process, Grey relational analysis optimization method is used. The optimal machinability conditions of AISI 304L stainless steel with coated carbide insert are successfully determined in this study.
\end{abstract}

DOI: 10.12693/APhysPolA.131.349

PACS/topics: 81.05.--t

\section{Introduction}

Machining has maintained its importance for years and the research in this field has been closely followed by the manufacturers. Every act of manufacturing has a cost and there are some factors which determine these costs. The cost of cutting tools and the cost of the workpiece can be considered as the two important factors in question. Thus, to lower the manufacturing cost and buy the product on cheap, those factors should be taken into consideration.

For the cutting tools to be long lived and to prevent the waste of the raw material, while producing the workpiece with the required level of quality, the need for the optimization of the cutting performance and conditions has arisen. To achieve that, the factors which affect the life of the cutting tools and determine the quality of the workpiece have been investigated by the scientists. The research has revealed the fact that there are a number of parameters and conditions in turning, which affect the above-mentioned factors $[1,2]$. Tool manufacturers are continuously improving their materials, offering new coatings for cutting edges and modifying the geometry of cutting inserts. These are geometric properties of the cutting tool, tip angles, approach angle, feed, cutting speed, depth of cut, coatings, cooling liquid, chip breaker form, workpiece, rigidity of the cutting tool, wiper geometry etc. [1-4]. Wiper geometry is formed by three curves to form a circular arc edge. The nose of wiper provides less profile height on the surface, that is formed by the cutting edge, resulting in a smooth turning surface. Insert with wiper has high efficiency when used for finish and semi-finish turning. The surface quality remains the same even at double feed rate [5]. Proper selection of these parameters, according to the properties of workpiece material, reduces the cost of manufacturing

\footnotetext{
*e-mail: muay@marmara.edu.tr
}

and the applied energy, lengthens the life of the cutting tool and increases the surface quality of the manufactured product [4-8]. When all these are taken into consideration, it is obvious that the selection of the cutting parameters in turning is very essential.

The machining of stainless steel inherently generates high cutting temperature, which not only reduces tool life but also impairs the workpiece surface quality $[9,10]$. Obtaining the desired surface quality is very important for the functional maintenance of a part [11-15]. One of the stainless steel family materials, most commonly used in the production facilities is steel with austenitic structure. The austenitic stainless steels structure has a combination of good mechanical properties and good corrosion resistance [11].

In this study, an experimental investigation of cutting forces and surface roughness after machining in turning of AISI 304L stainless steel using wiper and conventional insert cutting tools are presented. The influences of feed rate, depth of cut, corner radius and dry cutting condition on the surface roughness and the cutting force were examined. In order to optimize the turning process, Grey relational analysis Taguchi optimization method was used. The optimal machinability of AISI 304L stainless steel with coated carbide insert was successfully determined in this study.

\section{Materials and equipment}

The samples used in the experimental study had the shape of a rod. Their length was $130 \mathrm{~mm}$ and diameter was $25 \mathrm{~mm}$. Chemical composition of AISI 304L stainless steel is presented in Table I. A Johnford TC 35 CNC Fanuc 0T CNC lathe was used.

TABLE I

Chemical composition AISI 304L stainless steel.

\begin{tabular}{c|c|c|c|c|c|c}
\hline \hline $\mathrm{C}$ & $\mathrm{Mn}$ & $\mathrm{Cr}$ & $\mathrm{Mo}$ & $\mathrm{Ni}$ & $\mathrm{Co}$ & $\mathrm{Cu}$ \\
\hline 0.04 & 0.78 & 15.9 & 0.40 & 4.69 & 0.06 & 3.4
\end{tabular}




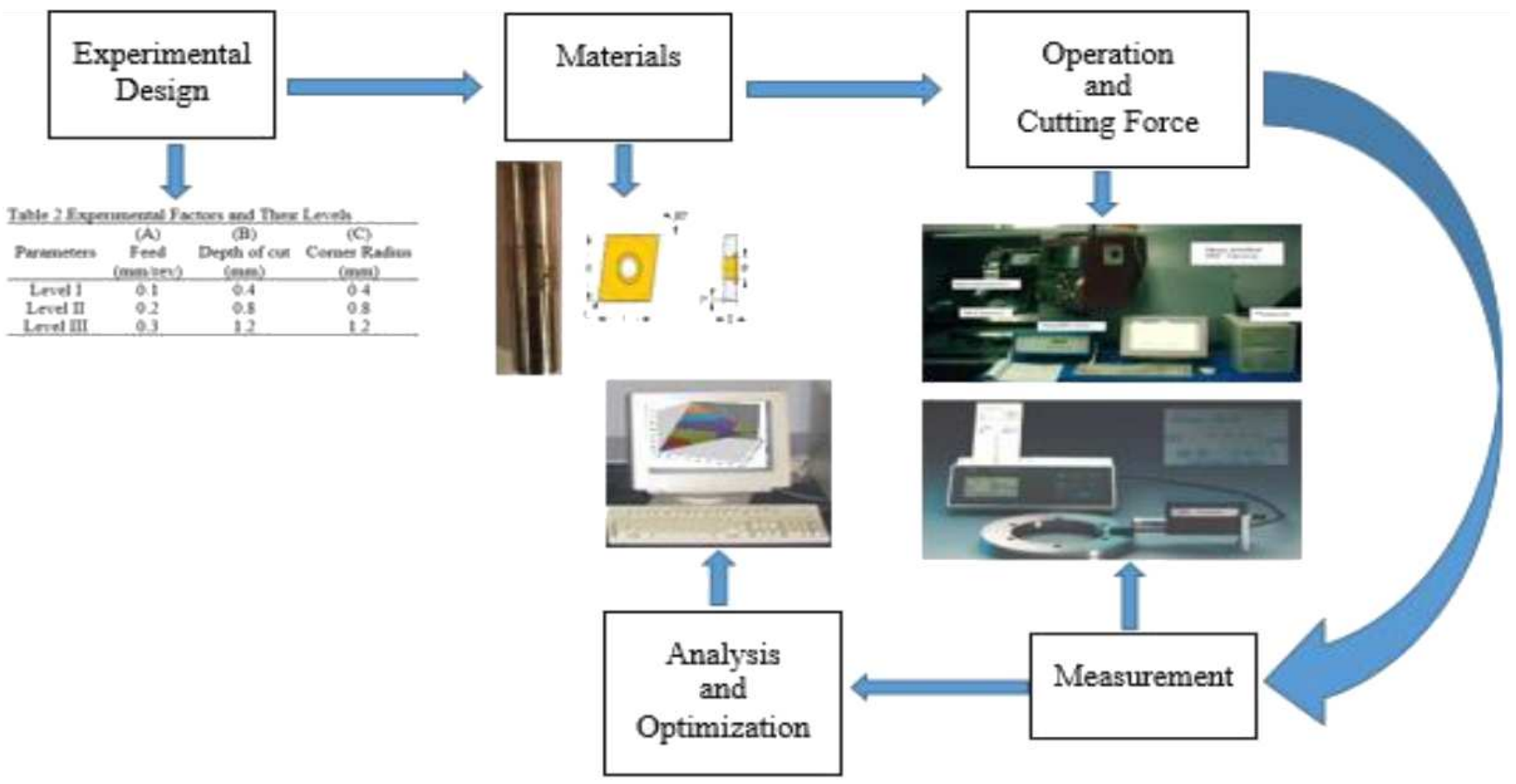

Fig. 1. Experimental setup.

TABLE II were performed on the machined surfaces to determine

Experimental factors and their levels. the $R a$ values. For the force measurements, Kistler 9121 force sensor, Kistler 5019b charge amplifier and Dyno-

\begin{tabular}{c|c|c|c}
\hline \hline Parameter & $\begin{array}{c}\text { (A) Feed } \\
{[\mathrm{mm} / \mathrm{rev}]}\end{array}$ & $\begin{array}{c}\text { (B) Depth } \\
\text { of cut }[\mathrm{mm}]\end{array}$ & $\begin{array}{c}\text { (C) Corner } \\
\text { radius }[\mathrm{mm}]\end{array}$ \\
\hline Level I & 0.1 & 0.4 & 0.4 \\
Level II & 0.2 & 0.8 & 0.8 \\
Level III & 0.3 & 1.2 & 1.2
\end{tabular}

In the experimental study, Kennametal KC5010 PVD TiAlN-coated conventional (FF) and wiper (FW) inserts were used. The surface roughness value and hardness on the work-piece obtained after the machining process were measured by MAHR-Perth meter. Three measurements Ware analysis program were used. Schematic drawing of the experimental setup is given in Fig. 1.

For the experimental design Taguchi method was employed.

$$
\mathrm{S} / \mathrm{N}(\eta)=-10 \log \left[\frac{1}{n} \sum_{i=1}^{n} y_{i}^{2}\right] .
$$

Experimental factors and their levels were presented in Table II for L9 experiment design. Results of surface roughness and cutting force are shown in Table III.

TABLE III

Taguchi L $\mathrm{L}_{9}$ experiment design, surface roughness and cutting force results.

\begin{tabular}{c|c|c|c|c|c|c|c|c|c|c}
\hline \hline $\begin{array}{c}\text { Exp. } \\
\text { No. }\end{array}$ & Variables & $\begin{array}{c}(\mathrm{A}) \\
f \\
{[\mathrm{~mm} / \mathrm{rev}]}\end{array}$ & $\begin{array}{c}(\mathrm{B}) \\
d \\
{[\mathrm{~mm}]}\end{array}$ & $\begin{array}{c}(\mathrm{C}) \\
r \\
{[\mathrm{~mm}]}\end{array}$ & $\begin{array}{c}\text { Surface } \\
\text { roughness } \\
{[\mu \mathrm{m}](\mathrm{FF})}\end{array}$ & $\begin{array}{c}\text { Surface } \\
\text { roughness } \\
{[\mu \mathrm{m}](\mathrm{FW})}\end{array}$ & $\begin{array}{c}\text { Cutting } \\
\text { force } \\
{[\mathrm{N}](\mathrm{FF})}\end{array}$ & $\begin{array}{c}\text { Cutting } \\
\text { force } \\
{[\mathrm{N}](\mathrm{FW})}\end{array}$ & $\begin{array}{c}\text { Hardness } \\
(\mathrm{HRC}) \\
(\mathrm{FF})\end{array}$ & $\begin{array}{c}\text { Hardness } \\
(\mathrm{HRC}) \\
(\mathrm{FW})\end{array}$ \\
\hline 1 & $\mathrm{~A}_{1} \mathrm{~B}_{1} \mathrm{C}_{1}$ & 1 & 1 & 1 & 0.72 & 1.04 & 255.80 & 338.76 & 28.6 & 27 \\
2 & $\mathrm{~A}_{1} \mathrm{~B}_{2} \mathrm{C}_{2}$ & 1 & 2 & 2 & 0.76 & 0.77 & 353.74 & 463.05 & 22.87 & 26 \\
3 & $\mathrm{~A}_{1} \mathrm{~B}_{3} \mathrm{C}_{3}$ & 1 & 3 & 3 & 0.54 & 0.64 & 389.15 & 589.21 & 21.27 & 24.8 \\
4 & $\mathrm{~A}_{2} \mathrm{~B}_{1} \mathrm{C}_{2}$ & 2 & 1 & 2 & 1.41 & 0.9 & 287.37 & 497.50 & 29.47 & 26 \\
5 & $\mathrm{~A}_{2} \mathrm{~B}_{2} \mathrm{C}_{3}$ & 2 & 2 & 3 & 1.24 & 0.81 & 348.45 & 567.30 & 23.23 & 26 \\
6 & $\mathrm{~A}_{2} \mathrm{~B}_{3} \mathrm{C}_{1}$ & 2 & 3 & 1 & 2.01 & 1.26 & 382.33 & 638.43 & 26.9 & 24.3 \\
7 & $\mathrm{~A}_{3} \mathrm{~B}_{1} \mathrm{C}_{3}$ & 3 & 1 & 3 & 1.13 & 0.84 & 278.33 & 494.16 & 27.63 & 26 \\
8 & $\mathrm{~A}_{3} \mathrm{~B}_{2} \mathrm{C}_{1}$ & 3 & 2 & 1 & 2.50 & 1.43 & 386.48 & 555.86 & 25.93 & 25 \\
9 & $\mathrm{~A}_{3} \mathrm{~B}_{3} \mathrm{C}_{2}$ & 3 & 3 & 2 & 2.13 & 0.97 & 487.38 & 676.09 & 23.63 & 28.73
\end{tabular}




\subsection{Taguchi-based Grey relational analysis method}

The obtained experimental results and the determined parameters were optimized using Taguchi-based Grey method. In regression model, research is carried out by calculating an equation between dependent and independent parameters. The Taguchi method uses a special design of orthogonal arrays to study the entire parameter space with a small number of experiments only.

Experimental design was done using Taguchi method. Hence, it has been possible to reach more comprehensive results with doing less experiment. In this sense, time and money have been used more efficiently [16, 17]. While a single outcome is optimized in the Taguchi method, multiple outcomes can be optimized in a Grey relational analysis [18]. In this study, Taguchi method was used in the experimental design step, Grey relational analysis method was used in the optimization step.

Grey relational analysis optimization process was carried out in the following three steps [18].

1. Normalization of experimental results (the lowestthe best).

2. Calculation the Grey relational coefficient.

3. Calculation of the Grey relational degree.

4. Determination of optimal experiment parameters.

In the normalization step, the experimental results were normalized using the following equation, according to "the lowest - the best" principle.

$$
x_{i}(k)=\frac{\max y_{i}(k)-y_{i}(k)}{\max y_{i}(k)-\min y_{i}(k)},
$$

where, $x_{i}(k)$ refers to the value at the $i$ th series and $k$ th row after normalization process, $\min y_{i}(k)$ refers to the minimum value of the $i$ th series, $\max y_{i}(k)$ refers to the maximum value of the $i$ th series and $y_{i}(k)$ refers to the original value at the $i$ th series and $k$ th row.

In the second step, Grey relational coefficient was calculated via Eq. (3)

$$
\xi_{i}(k)=\frac{\Delta \min +\zeta \Delta \max }{\Delta 0_{i}(k)+\zeta \Delta \max } .
$$

Here, $\zeta$ is a distinguishing coefficient between 0 and 1 , $\Delta 0_{i}$ is the amount of deviation between the reference series and the normalization values, $\Delta$ min refers to the minimum value of the deviation sequence from the reference series and $\Delta$ max refers to the maximum value of deviation sequence from the reference series.

In step three, Grey relational degree was calculated using Eq. (4)

$$
\gamma_{i}=\frac{1}{n} \sum_{k-1}^{n} \xi_{i}(k) .
$$

\section{Results and discussion}

Influence of the cutting parameters and the effect of cutting geometry and parameters on surface roughness $R a$ and cutting force $N$ on turning of a AISI 304L stainless steel with Kennametal KC5010 PVD TiAlN-coated conventional $(\mathrm{FF})$ and wiper $(\mathrm{FW})$ inserts is discussed in this section.

Grey relational analysis method was applied to the experimental results, as shown in Table III. The normalized data, delta values and Grey relational grade results are given in Tables IV and V.

\begin{tabular}{|c|c|c|c|c|c|c|c|c|c|c|c|}
\hline \multirow{3}{*}{$\begin{array}{c}\text { Exp. } \\
\text { no. }\end{array}$} & \multirow{3}{*}{$\begin{array}{c}\text { Cutting } \\
\text { force } \\
{[\mathrm{N}]}\end{array}$} & \multirow{3}{*}{$\begin{array}{c}\text { Surface } \\
\text { roughness } \\
{[\mu \mathrm{m}]}\end{array}$} & \multirow{3}{*}{$\begin{array}{c}\text { Hardness } \\
(\mathrm{HRC})\end{array}$} & \multicolumn{3}{|c|}{ Normalized data } & \multicolumn{3}{|c|}{ Delta values } & \multirow{2}{*}{\multicolumn{2}{|c|}{$\begin{array}{l}\text { Grey relational } \\
\text { grade }\end{array}$}} \\
\hline & & & & \multirow{2}{*}{$\begin{array}{c}\begin{array}{c}\text { Cutting } \\
\text { force }\end{array} \\
\end{array}$} & \multirow{2}{*}{$\begin{array}{c}\text { Surface } \\
\text { roughness }\end{array}$} & \multirow[b]{2}{*}{ Hardness } & \multirow{2}{*}{$\begin{array}{c}\text { Cutting } \\
\text { force }\end{array}$} & \multirow{2}{*}{$\begin{array}{c}\text { Surface } \\
\text { roughness }\end{array}$} & \multirow[b]{2}{*}{ Hardness } & & \\
\hline & & & & & & & & & & Value & Rank \\
\hline 1 & 255.8 & 0.72 & 28.6 & 1.000 & 0.908 & 0.106 & 0.000 & 0.092 & 0.894 & 0.735 & 1 \\
\hline 2 & 353.74 & 0.76 & 22.87 & 0.577 & 0.888 & 0.805 & 0.423 & 0.112 & 0.195 & 0.679 & 2 \\
\hline 3 & 389.15 & 0.54 & 21.27 & 0.424 & 1.000 & 1.000 & 0.576 & 0.000 & 0.000 & 0.732 & 3 \\
\hline 4 & 287.37 & 1.41 & 29.47 & 0.864 & 0.556 & 0.000 & 0.136 & 0.444 & 1.000 & 0.658 & 4 \\
\hline 5 & 348.45 & 1.24 & 23.23 & 0.600 & 0.643 & 0.761 & 0.400 & 0.357 & 0.239 & 0.569 & 5 \\
\hline 6 & 382.33 & 2.01 & 26.9 & 0.454 & 0.250 & 0.313 & 0.546 & 0.750 & 0.687 & 0.439 & 6 \\
\hline 7 & 278.33 & 1.13 & 27.63 & 0.903 & 0.699 & 0.224 & 0.097 & 0.301 & 0.776 & 0.731 & 7 \\
\hline 8 & 386.48 & 2.5 & 25.93 & 0.436 & 0.000 & 0.432 & 0.564 & 1.000 & 0.568 & 0.402 & 8 \\
\hline 9 & 487.38 & 2.13 & 23.63 & 0.000 & 0.189 & 0.712 & 1.000 & 0.811 & 0.288 & 0.357 & 9 \\
\hline
\end{tabular}

TABLE IV

Normalized data, delta values and Grey relational grade for conventional insert tool.

The Grey relational degrees, related to each experiment result were calculated and the experimental results were ranked in order from highest Grey relational degree. Results are presented in Fig. 2 and Table VI.
As seen from the Table VI, A1 (feed of $0.1 \mathrm{~mm} / \mathrm{rev}$ ), B1 (depth of cut of $0.4 \mathrm{~mm}$ ), and $\mathrm{C} 2$ (corner radius of $0.8 \mathrm{~mm}$ ) were selected as the optimal parameters. The optimal parameter values will provide the lowest surface roughness and cutting force values. 
TABLE V

Normalized data, delta values and Grey relational grade for wiper insert tool.

\begin{tabular}{|c|c|c|c|c|c|c|c|c|c|c|c|}
\hline \multirow{3}{*}{$\begin{array}{c}\text { Exp. } \\
\text { no. }\end{array}$} & \multirow{3}{*}{$\begin{array}{c}\text { Cutting } \\
\text { force } \\
{[\mathrm{N}]}\end{array}$} & \multirow{3}{*}{$\begin{array}{c}\text { Surface } \\
\text { roughness } \\
{[\mu \mathrm{m}]}\end{array}$} & \multirow{3}{*}{$\begin{array}{c}\text { Hardness } \\
(\mathrm{HRC})\end{array}$} & \multicolumn{3}{|c|}{ Normalized data } & \multicolumn{3}{|c|}{ Delta values } & \multirow{2}{*}{\multicolumn{2}{|c|}{$\begin{array}{l}\text { Grey relational } \\
\text { grade }\end{array}$}} \\
\hline & & & & \multirow{2}{*}{$\begin{array}{c}\text { Cutting } \\
\text { force }\end{array}$} & \multirow{2}{*}{$\begin{array}{c}\text { Surface } \\
\text { roughness }\end{array}$} & \multirow[b]{2}{*}{ Hardness } & \multirow{2}{*}{$\begin{array}{c}\text { Cutting } \\
\text { force }\end{array}$} & \multirow{2}{*}{\begin{tabular}{c|} 
Surface \\
roughness
\end{tabular}} & \multirow[b]{2}{*}{ Hardness } & & \\
\hline & & & & & & & & & & Value & Rank \\
\hline 1 & 338.76 & 1.04 & 27 & 1.000 & 0.494 & 0.391 & 0.000 & 0.506 & 0.609 & 0.649 & 1 \\
\hline 2 & 463.05 & 0.77 & 26 & 0.632 & 0.835 & 0.616 & 0.368 & 0.165 & 0.384 & 0.664 & 2 \\
\hline 3 & 589.21 & 0.64 & 24.8 & 0.258 & 1.000 & 0.887 & 0.742 & 0.000 & 0.113 & 0.701 & 3 \\
\hline 4 & 497.5 & 0.9 & 26 & 0.529 & 0.671 & 0.616 & 0.471 & 0.329 & 0.384 & 0.559 & 4 \\
\hline 5 & 567.3 & 0.81 & 26 & 0.323 & 0.785 & 0.616 & 0.677 & 0.215 & 0.384 & 0.562 & 5 \\
\hline 6 & 638.43 & 1.26 & 24.3 & 0.112 & 0.215 & 1.000 & 0.888 & 0.785 & 0.000 & 0.375 & 6 \\
\hline 7 & 494.16 & 0.84 & 26 & 0.539 & 0.747 & 0.616 & 0.461 & 0.253 & 0.384 & 0.592 & 7 \\
\hline 8 & 555.86 & 1.43 & 25 & 0.356 & 0.000 & 0.842 & 0.644 & 1.000 & 0.158 & 0.385 & 8 \\
\hline 9 & 676.09 & 0.97 & 28.73 & 0.000 & 0.582 & 0.000 & 1.000 & 0.418 & 1.000 & 0.439 & 9 \\
\hline
\end{tabular}

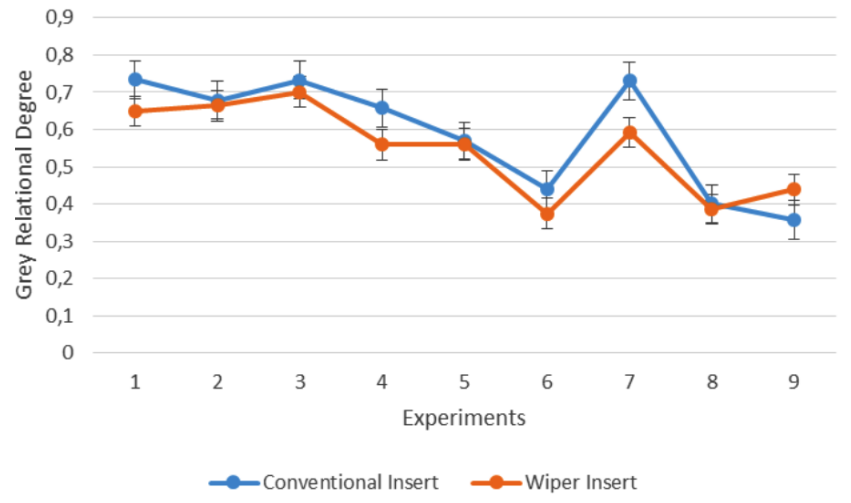

Fig. 2. Grey relational degrees for each experiment.

TABLE VI

Grey relational degrees of the factor levels for conventional insert tool.

\begin{tabular}{c|c|c|c}
\hline \hline Levels & $\begin{array}{c}\text { (A) Feed } \\
{[\mathrm{mm} / \mathrm{rev}]}\end{array}$ & $\begin{array}{c}\text { (B) Depth } \\
\text { of cut }[\mathrm{mm}]\end{array}$ & $\begin{array}{c}\text { (C) Corner } \\
\text { radius }[\mathrm{mm}]\end{array}$ \\
\hline Level 1 & 1.301 & 1.204 & 0.872 \\
Level 2 & 0.830 & 0.880 & 0.996 \\
Level 3 & 0.686 & 0.733 & 0.948
\end{tabular}

\section{Conclusions}

This study of the machinability of AISI 304L stainless steel alloy material with Kennametal KC5010 PVD TiAlN-coated conventional (FF) and wiper (FW) inserts has produced useful results. The criteria for the machinability are surface roughness, cutting force and material hardness. Three control factors which were considered to be effective in creating the most suitable conditions for the criteria (feed rate, depth of cut and corner radius) were chosen at three different levels and applied in the experimental study. Below is the summary of the results:
- Based on the Grey relational analysis, the optimal cutting parameters were $\mathrm{A} 1 \mathrm{~B} 1 \mathrm{C} 2$ for surface roughness and cutting force, i.e. feed of $0.1 \mathrm{~mm} / \mathrm{rev}$, depth of cut of $0.4 \mathrm{~mm}$ and corner radius of $0.8 \mathrm{~mm}$.

- Taguchi method is beneficial for the experimental design of the machinability of AISI 304L stainless steel alloy material. Having optimized parameters is also fruitful for keeping the response values at required levels.

- The test results prove the effectiveness of the wiper inserts in providing the excellent surface roughness. The results also suggest that the use of the wiper insert is an effective way to significantly increase cutting efficiency, without changing the machined surface roughness in high feed turning operations.

\section{References}

[1] M.C. Shaw, Metal cutting principles, Oxford University Press, 1984.

[2] M.C. Cakır, Modern Machining Methods, VIPAS A.S., 2000, p. 349.

[3] A. Kurt, Ph.D. Thesis, Gazi University, Institute of Pure and Applied Sciences, 2006.

[4] W.S. Lin, B.Y. Lee, C.L. Wu, Int. J. Mater. Proc. Technol. 108, 286 (2001).

[5] W. Stachurski, B. Kruszynski, S. Midera, Mech. Mech. Engin. 16, 25 (2012).

[6] H. Saglam, S. Yaldiz, F. Unsacar, Mater. Design 28, 101 (2007).

[7] H. Gokkaya, M. Nalbant, Electr. J. Mach. Technol. 2, 33 (2006).

[8] M. Field, J.F. Kahles, W.P. Koster, Metals Handbook-Machining-16, 9th ed., ASM International Materials, Park-Ohio 1989, p. 19.

[9] A.S. Kumar, A.R. Durai, T. Sornakumar, J. Mater. Proc. Technol. 173, 151 (2006). 
[10] M.Y. Noordin, V.C. Venkatesh, S. Sharif, J. Mater. Proc. Technol. 185, 83 (2007).

[11] I. Korkut, M. Kasap, I. Çiftçi, U. Şeker, Mater. Design 25, 300 (2004).

[12] M.Y. Noordin, D. Kurniawan, S. Sharif, Int. J. Prec. Technol. 1, 75 (2007).

[13] I.S. Jawahir, E. Brinksmeier, R. M'Saoubi, D.K. Aspinwall, J.C. Outeiro, D. Meyer, D. Umbrello, A.D. Jayal, CIRP Ann.-Manufact. Technol. 60, 603 (2011).

[14] M. Elbah, M.A. Yallese, H. Aouici, T. Mabrouki, J.-F. Rigal, Measurement 46, 3041 (2013).
[15] W. Grzesik, T. Wanat, Int. J. Mach. Tools Manufac. 46, 1988 (2006).

[16] W.H. Yang, Y.S. Tarng, Int. J. Mater. Process. Technol. 84, 122 (1998).

[17] K. Venkatesan, R. Ramanujam, V. Saxena, N. Chawdhury, V. Choudhary, J. Engin. Appl. Sci. 9, 250 (2014).

[18] M. Kurt, S. Hartomacioğlu, B. Mutlu, U. Köklü, $M a-$ ter. Technol. 46, 205 (2012). 